\title{
Business Trends in Selected Areas of Indian Banking - An Overview
}

\author{
Roy John \\ Research Scholar, JJT University, Jhunjhunu, Rajasthan
}

\begin{abstract}
Banking has grown from safekeeping of coins, the store of value, to the touch of fingertips in digital era. The business trends in Banking has ups and downs in India and abroad. However, the Indian Banking industry has been witnessing more or less a constant growth story and has shown resilience to bounce back in times of crisis. When compared with the global banking trends on profitability, asset quality and capital positions, the Indian banking sector did not appear to be an exceptional under-performer. This paper analyzes the trends in certain sections of banking business in India such as branch growth, total business growth etc. along with special mention to trends in Priority Sector lending in last five years.

Key Words: Business trends in Banking, Priority Sector Lending, and population per branch
\end{abstract}

\section{Introduction}

The Coins, in the ancient times, being the store of value, needed to be kept in a safe place. Ancient homes didn't have the benefit of a steel safe, therefore, most wealthy people held accounts at their temples. The priests and temple workers whom one hoped were honest, occupied the temples, adding a sense of security. Records suggest that temples from Greece, Rome, Egypt and Ancient Babylon loaned money out, in addition to keeping it safe. The fact that most temples were financial store houses, was a reason to make it a target during wars. Banking has long evolved since then, but the basic business practices have not changed. Banks issue credit to people who need it, but demand interest. Though the business model has undergone sea changes, till today a bank's purpose is to make loans and protect depositors' money. Even in the era of digital banking the primary function of the banks stands as the strong pillar in Banking business.

The Banking in India, in the modern sense, originated in the last decades of the 18th century. Among the first banks were the Bank of Hindustan, which was established in 1770 and liquidated in 1829-32; and the General Bank of India, established in 1786 but failed in 1791. State Bank of India was originated as the Bank of Calcutta in June 1806 and was renamed as Bank of Bengal in 1809. This was the first of the three presidency banks which were funded by a presidency government, and the others were the Bank of Bombay and the Bank of Madras. The three banks were merged in 1921 to form the Imperial Bank of India, which became the State Bank of India in 1955. Until the Reserve Bank of India was established in 1935, the presidency banks were acting as the bankers to the government.

State Bank of India was given control of eight associated banks under the SBI (Subsidiary Banks Act) 1959. In 1969 the Indian government nationalized 14 major private banks and in 1980, nationalized six more private banks. These nationalized banks are the majority of lenders in the Indian economy. The State Bank group, nationalized Banks and Regional Rural Banks together operate $83 \%$ of total branches in the country.

DEPOSITS AND CREDIT OF SCHEDULED COMMERCIAL BANKS as ON 31/03/2015

\begin{tabular}{|c|c|c|c|c|c|}
\hline \multicolumn{6}{|l|}{ (Amount in`Million) } \\
\hline & & & & & \\
\hline \multirow{3}{*}{ BANK GROUP } & \multirow[b]{2}{*}{ No. of Offices } & \multicolumn{2}{|l|}{ DEPOSITS } & \multicolumn{2}{|l|}{ CREDIT } \\
\hline & & $\begin{array}{ll}\text { No. } & \text { of } \\
\text { Accounts }\end{array}$ & Amount & $\begin{array}{ll}\text { No. } & \text { of } \\
\text { Accounts }\end{array}$ & $\begin{array}{l}\text { Amount } \\
\text { Outstanding }\end{array}$ \\
\hline & 1 & 2 & 3 & 4 & 5 \\
\hline \multirow{2}{*}{$\begin{array}{l}\text { STATE BANK OF INDIA } \\
\text { AND ITS ASSOCIATES }\end{array}$} & 23947 & 388034612 & 19552169.7 & 26928225 & 14808717.7 \\
\hline & (18.4) & $(26.9)$ & $(21.9)$ & $(18.7)$ & $(21.5)$ \\
\hline \multirow[t]{2}{*}{ NATIONALISED BANKS } & 65764 & 708285313 & 45472836.3 & 52921946 & 34474392.7 \\
\hline & $(50.4)$ & $(49.2)$ & (51.0) & (36.7) & (50.1) \\
\hline \multirow[t]{2}{*}{ FOREIGN BANKS } & 332 & 3541847 & 3944052.4 & 5303666 & 3355086.6 \\
\hline & $(0.3)$ & $(0.2)$ & $(4.4)$ & $(3.7)$ & $(4.9)$ \\
\hline REGIONAL & 20005 & 181882984 & 2678906.6 & 22228383 & 1812305.0 \\
\hline
\end{tabular}


Business trends in selected areas of Indian banking - an overview

\begin{tabular}{|l|l|l|l|l|l|} 
BANKS & $(15.3)$ & $(12.6)$ & $(3.0)$ & $(15.4)$ & $(2.6)$ \\
\hline \multirow{2}{*}{$\begin{array}{l}\text { PRIVATES SANKS } \\
\text { BASTOR }\end{array}$} & 20434 & 158147527 & 17573147.0 & 36857416 & 14334223.2 \\
\cline { 2 - 6 } & $(15.7)$ & $(11.0)$ & $(19.7)$ & $(25.6)$ & $(20.8)$ \\
\hline \multirow{2}{*}{$\begin{array}{l}\text { ALL SCHEDULED } \\
\text { COMMERCIAL BANKS }\end{array}$} & $\mathbf{1 3 0 4 8 2}$ & $\mathbf{1 4 3 9 8 9 2 2 8 3}$ & $\mathbf{8 9 2 2 1 1 1 2 . 1}$ & $\mathbf{1 4 4 2 3 9 6 3 6}$ & $\mathbf{6 8 7 8 4 7 2 5 . 2}$ \\
\cline { 2 - 6 } & $\mathbf{( 1 0 0 . 0 )}$ & $\mathbf{( 1 0 0 . 0 )}$ & $\mathbf{( 1 0 0 . 0 )}$ & $\mathbf{( 1 0 0 . 0 )}$ & $(\mathbf{1 0 0 . 0 )}$ \\
\hline
\end{tabular}

Table 1: Source: RBI Website

The Indian banking sector is broadly classified into development banks and scheduled banks. There are nonscheduled banks which are minor players in the organized market. The scheduled banks are those included under the 2nd Schedule of the Reserve Bank of India Act, 1934. The scheduled banks are further classified into: nationalized banks; State Bank of India and its associates; Regional Rural Banks (RRBs); foreign banks; and other Indian private sector banks. The term commercial banks refer to both scheduled and non-scheduled commercial banks regulated under the Banking Regulation Act, 1949. The private sector banks are further classified into old generation, which came into existence before the liberalization period in 1991 and new generation private banks, which came into existence after 1991.

\section{Objective}

The objective of this paper is to explain the changing pattern of banking trends, to analyze the trends in credit, deposit in recent times. Also, an attempt is made to understand the approaches of different banks which belong to same segment owners towards the business prepositions.

\section{Methodology}

The secondary data on Indian Banking with annual reports of different banks, various books, journals and periodicals and websites and references of RBI and other publishers.

\section{Number of commercial Banks}

The number of commercial banks in 1969 was 89 . There is a growth of $85 \%$ in number of banks. The number of banks have been reduced from 1692011 to 152 in 2015. This was manly due to the consolidation of Regional Rural Banks, and resultant reduction in their number to 56. There was a consolidation of their numbers from 196 in 2005 to 56 in 2015.

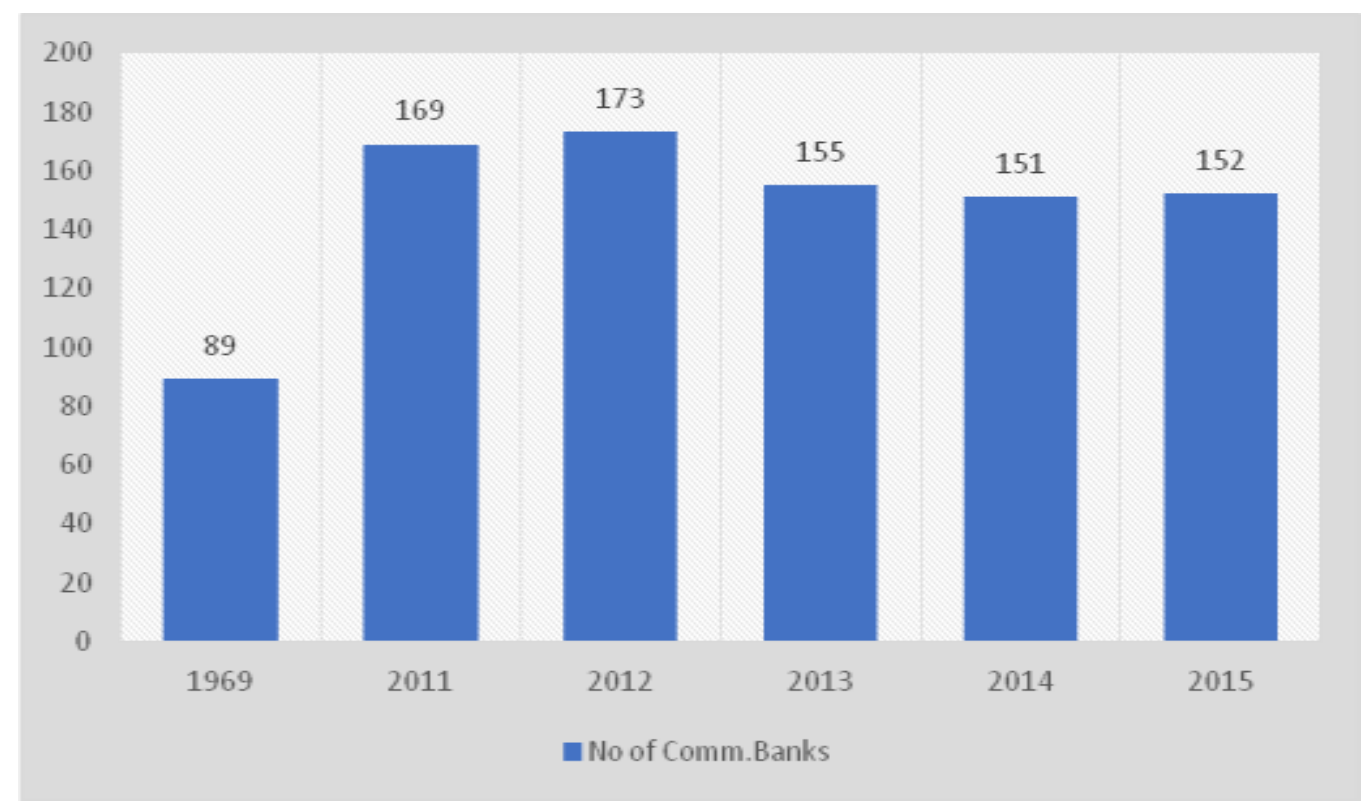

Figure:1 Source RBI website

\section{Total Business}

The total business in the formal banking sector was Rs.82 billion in 1962 and has grown to Rs.153987 billion in 2015. 


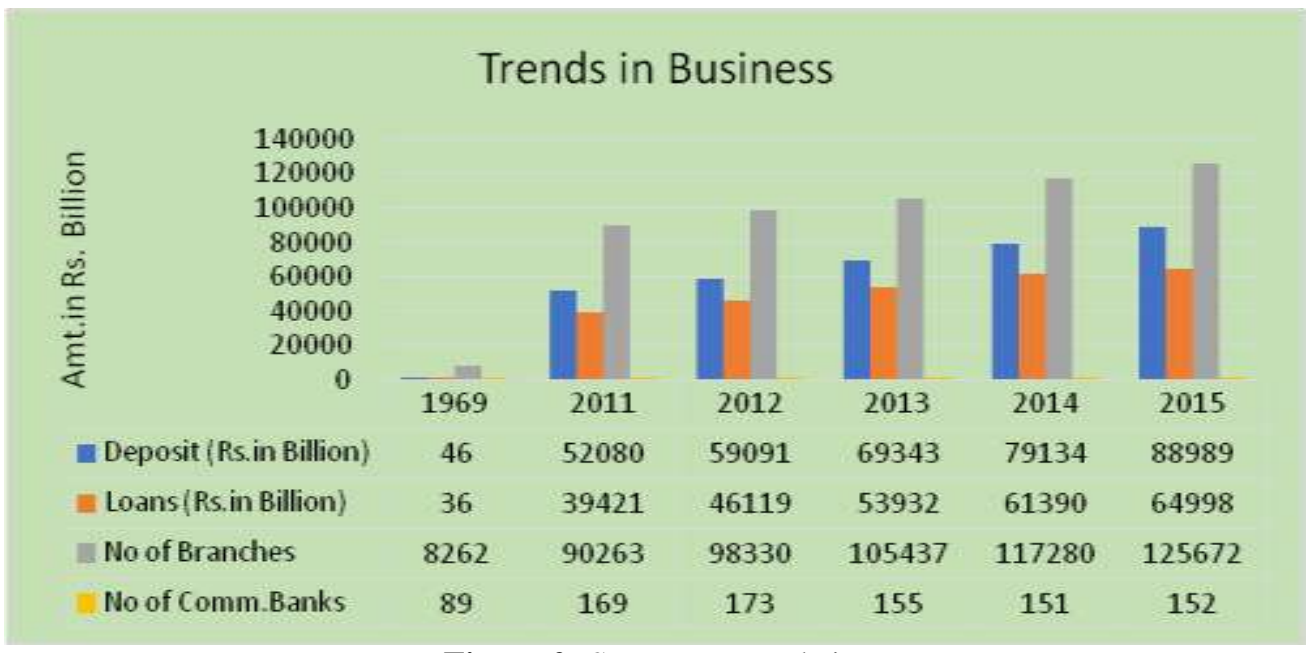

Figure 2: Source RBI website

The number of commercial banks witnessed only .85 times growth, whereas the number of branches had grown 15 times and business had grown 1877 times. The major part of the national savings was routed through the formal banking system after the nationalization in 1969 and 1980. Also, the thrust of the government for funding the rural and manufacturing sector had contributed to the growth in credit facilities. Introduction of lead bank scheme, a separate structure of Regional Rural Banks etc have helped the banks to grow the level they attained today.

\section{Population per branch}

The density per bank branch in 1969 was 64000 whereas the same in 10300 as on 31/3/2015. However, the banking services for more than $40 \%$ of the population remain non accessible, which has forced the government to embark major financial inclusion measures.

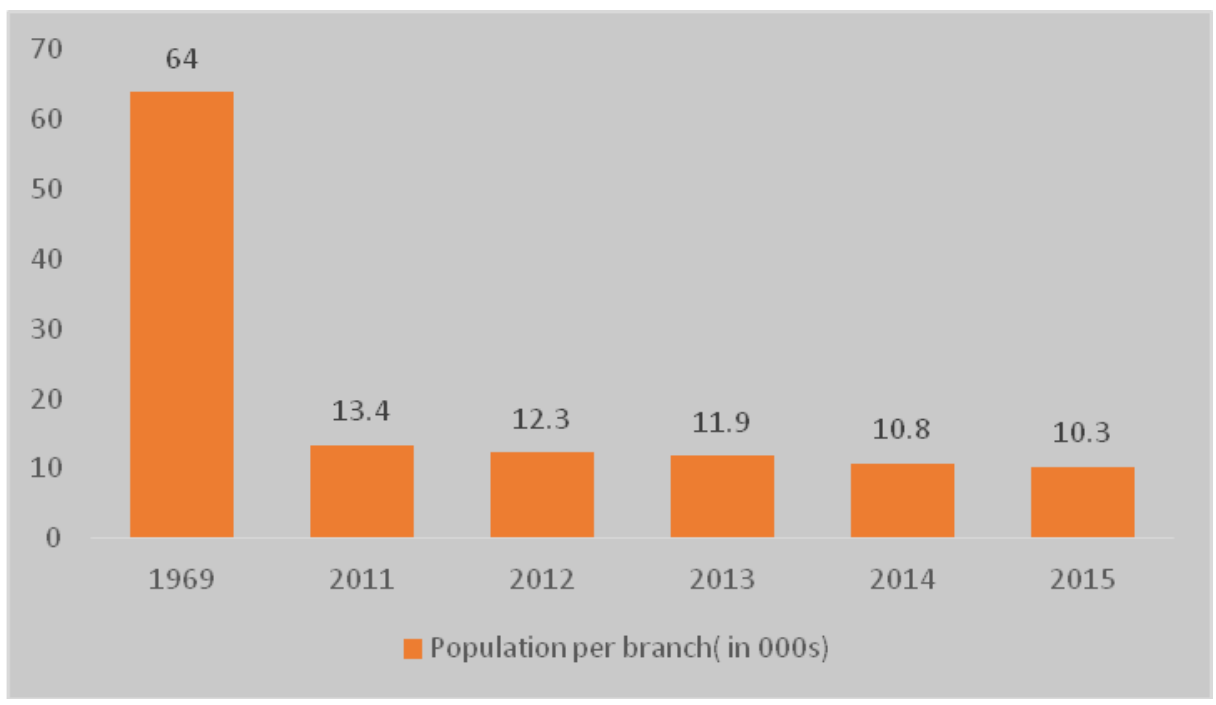

Figure 3

The population data of 10300 in 2015 seems impressive, but it is to be noted that a disproportionate percent of the branches are centered in Urban areas. The government has initiated financial inclusion plans such as Prime Ministers Jan Dhan Yojana (PMJDY), under which 28.23 accounts were opened. The government is consciously looking for other avenues than the brick and mortar branches, such as Banking correspondents, Mithras etc. to outreach the rural mass for banking services.

\section{A special mention: Advances to Priority Sector}

The Priority sector was defined by Dr. K S Krishnaswamy Committee in 1972 after the National Credit Council emphasized that there should be a larger involvement of the commercial banks in the priority sector. The objective of priority sector lending programme was to ensure that adequate institutional credit flows into 
some vulnerable sectors of the economy as these sectors may not attract banks' lending, once they think of the profitability angle. The banks were given a target of $33.33 \%$ as share of the priority sector in the total bank credit and this was raised to $40 \%$ later.

The regulations are modified periodically by setting limits for subsectors and other qualifications for the beneficiary groups. In case targets are not met, banks have to finance the development programmes implemented by the government under the sectors concerned through bonds issued by developmental institutions. From 2016, Reserve Bank of India has launched Priority Sector Lending Certificates so that banks can trade the loan certificates given to the different sectors to meet their targets.

The Priority Sector Target:

\begin{tabular}{|l|l|}
\hline Category & Domestic \& Foreign Banks with more than 20 branches \\
\hline Total Priority Sector & $40 \%$ of ANBC \\
\hline Agriculture & $18 \%$ of ANBC \\
\hline Micro Enterprises & $7.5 \%$ of ANBC \\
\hline Weaker Section & $10 \%$ of ANBC \\
\hline
\end{tabular}

ANBC: Adjusted Net Bank Credit

\section{New Priority Sector Lending norms}

The RBI has modified Priority Sector Lending norms after the recommendations of the Internal Working Group in 2015. Changes in classification of the priority sectors and targets were also made asper the new norms. Following are the main eight categories of Priority Sector Lending

\section{Categories under priority sector}

1. Agriculture Sector: Within the 18 percent target for agriculture, a target of 8 percent of ANBC is prescribed for Small and Marginal Farmers.

2. Micro, Small and Medium Enterprises 7.5 percent.

3. Export Credit: Incremental export credit up to 2 percent for domestic banks and foreign banks with 20 branches and above.

4. Education: Loans to individuals for educational purposes including vocational courses upto Rs 10 lakh.

5. Housing Loans: Loans to individuals up to Rs 28 lakh in metropolitan centers (with population of ten lakh and above) and loans up to Rs 20 lakh in other centers for purchase/construction of a dwelling unit per family.

6. New Additions: Social Infrastructure: Bank loans up to a limit of Rs 5 crore per borrower for building social infrastructure for activities namely schools, health care facilities, drinking water facilities and sanitation facilities in Tier II to Tier VI centers.

7. Renewable Energy: Bank loans up to a limit of Rs 15 crore to borrowers (individual households- Rs 10 lakh) including for public utilities viz. street lighting systems, and remote village electrification.

8. Others: SHG, etc.

The Priority Sector norms of 2016 stipulate that banks should give $10 \%$ of their loans to the weaker sections. The Weaker sections consist of: Small Marginal Farmers, artisans, village and cottage industries with a credit limit upto Rs 1 lakh, beneficiaries of certain government sponsored schemes, SC/STs, SHGs, persons with disabilities, overdrafts upto Rs 5000 under PMJDY, distressed persons, individual women beneficiaries up to Rs 1 lakh, beneficiaries of differential interest rate regime.

The changes include new categories of PSL: medium enterprises, social infrastructure and renewable energy. A separate target for small and marginal farmers (7.5\%) and microenterprises (8\%) and weaker sections $(10 \%)$ and inclusion of food and agro processing units under agriculture are the major changes. The priority sector non-achievement will be assessed on quarterly average basis at the end of the respective year from 201617 onwards, instead of annual basis as at present.

In case of shortfall in sanctioning loans under priority sector targets, banks have to contribute to the funds of RIDF (Rural Infrastructure Development Fund) or and similar funds set up with National Bank of Agriculture and Rural Development (NABARD) / Small Industries Development Bank of India (SIDBI) / National Housing Bank (NHB). 


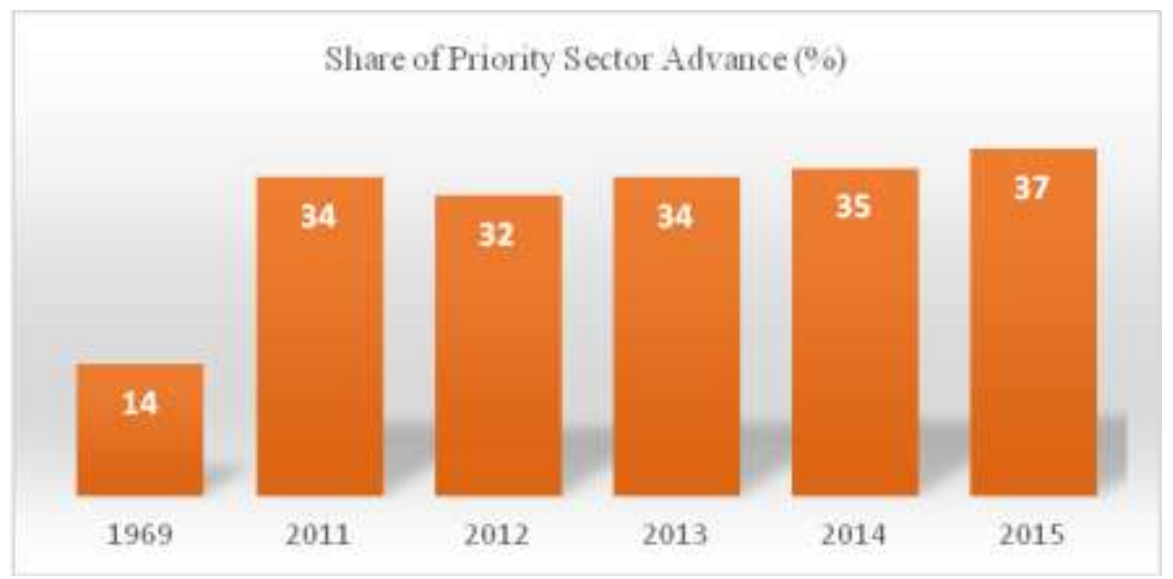

Figure: 4

The Priority sector share has been increased over the years, but has not touched the stipulated level of $40 \%$ of ANBC. The amount of credit to Priority Sector was increased from Rs.13371 billion to Rs.23781, registering a growth over Rs.10000 billion over five years. The banking business has expanded during the period and this could register and year to year growth of $3 \%$ only over the years.

\section{Conclusion}

The growth of Indian banking has been impressive since 1969. It has grown to serve the nation from negligible levels in 1969, the time of nationalization. Since then, the sector has grown in multitude. However, there are banks yet to achieve Priority Sector lending targets. This is due to the reluctance to serve low value business and fear of failing of loans due to uncertain monsoon, business climate etc. However, the value of credit to the primary and part of secondary sectors of economy, which consist of more than 65 per cent of the to total population is highly inadequate and the government has to intervene effectively to ensure that adequate credit is given to this sectors. Also, the study has seen that in spite of reduction in number of banks, the business volume has grown up substantially from 2012 to 2015. This has proved that the number of banks are not a deciding factor for the banking habits of the population to develop. With adoption to latest technology, launching of supplementary services, containing of Non-Performing Assets etc. the banks are capable to grow manifold in business irrespective of the number of branches or banks.

\section{Reference}

[1]. Ritika Gauba, The Indian banking Industry: Evolution, Transformation and Road Ahead, Pacific Business Review International, Volume 5, Issue 1 July 2012, page 85-97

[2]. Bharati Pathak, Indian Financial System (Pearson,2016)

[3]. Reserve Bank of India website: Basic Statics Return 2016

[4]. http://www.indianeconomy.net

[5]. Top 10 trends in Banking 2016, published by Capgemini, 2016.

[6]. FICCI-IBA Bankers Survey 2016 